\title{
Sosialisasi Model Pembelajaran Reading Berbasis Question Generation pada Guru Bahasa Inggris SMA/SMK/MA di Kecamatan Gunung Sari Kabupaten Lombok Barat
}

\author{
Lalu Thohir*, Muhammad Isnaini, Lalu Jaswadi Putera \\ Program studi Pendidikan Bahasa Inggris FKIP Universitas Mataram, Indonesia
}

\author{
Article history \\ Received: 30-01-2021 \\ Revised: 15-03-2021 \\ Accepted: 01-04-2021 \\ *Corresponding Author: \\ Lalu Thohir, \\ Program studi Pendidikan \\ Bahasa Inggris FKIP \\ Universitas Mataram, \\ Mataram, Indonesia;
}

Email: thohir@unram.ac.id

\begin{abstract}
Teachers play a very important role in improving human resources and preparing students to be able to face the challenges of the times. One of the ways that English teachers can take to fulfill these needs is through reading activities in which they can train the students to have critical, creative and active thinking skills. Question Generation is a learning activity where students are trained to ask or make questions about what they have read which consists of literal, inferential and evaluative questions. This Community Service program aimed to enhance the knowledge of the English teachers about a teaching reading strategy (Question Generation) and how to teach it to students. This program was carried out at SMAN 1 Gunung Sari and there were 20 English teachers of several high schools located in Gunung Sari sub-district were involved. The results shows that the participants look enthusiastic and active in participating in the existing series of activities, diligently paying attention and listening to the material presented by the team, actively discussing or asking questions related to materials presented and language learning problems. They also practiced in making questions for a text provided. In addition, the results from the questionnaire show that the participants welcomed this program because it could increase their knowledge and insight, and thus they hoped that there would be similar program in the future involving more teachers and materials dealing with teacher needs and problem solving.

Keywords: educate; reading; teaching; teacher
\end{abstract}

Abtrak: Guru mempunyai peranan yang sangat penting dalam meningkatkan Sumber Daya Manusia dan menyiapkan para peserta didik untuk mampu menghadapi tantangan zaman. Salah satu media yang dapat dimanfaatkan guru bahasa Inggris untuk memenuhi kebutuhan tersebut adalah melalui kegiatan membaca yang dapat melatih kemampuan berfikir kritis, kreatif dan aktif. Question Generation merupakan kegiatan belajar dimana peserta didik dilatih untuk membuat pertanyaan terhadap apa yang mereka sudah baca yang terdiri dari pertanyaan literal, inferential dan evaluative. Kegiatan Pengadian Pada Masyarakat (PPM) ini bertujuan menambah dan/atau memperkaya pengetahuan para guru bahasa Inggris tentang strategi membaca dan bagaimana mengajarakannya. Kegiatan PPM dilaksanakan di SMAN 1 Gunung Sari dan melibatkan 20 orang guru bahasa Inggris SMA, SMK dan MA se-kecamatan Gunung Sari. Hasil kegiatan PPM yang meliputi penyampaian materi, diskusi, latihan dan evaluasi menunjukkan bahwa para peserta terlihat antusias dan aktif dalam mengikuti rangkaian kegiatan PPM, tekun memperhatikan dan menyimak materi yang disampaikan, aktif berdiskusi atau tanya jawab terkait materi sosialisasi dan masalah pembelajaran bahasa Inggris dan juga praktik dalam membuat pertanyaan untuk teks yang mereka baca. Evaluasi kegiatan menunjukkan bahwa para peserta menyambut baik kegiatan ini dan berharap jika ada kegiatan serupa pada masa yang akan datang dengan melibatkan lebih banyak guru dan materi yang lebih fokus pada teacher needs dan problem solving.

Kata Kunci: didik; guru; membaca; pembelajaran 


\section{PENDAHULUAN}

Perkembangan zaman yang ditandai dengan era globalisasi dan diwarnai dengan berbagai masalah lingkungan hidup, kemajuan informasi, komunikasi dan teknologi (ICT) dan kebangkitan industri kreatif menuntut para guru untuk memberikan bekal yang memadai kepada para peserta didik sehingga mereka mampu bersaing dan menghadapi tantangan zaman dan guru mempunyai peran yang sangat penting dalam hal ini dan dalam meningkatkan SDM (Sumber Daya Manusia), dan tujuan tersebut, menurut Ekaningsih (2013), pendidikan dan pelatihan adalah suatu keharusan karena dengannya kualitas SDM dapat ditingkatkan, semakin tinggi frekuensi dan kualitas pendidikan dan pelatihan, semakin tinggi pula kompetensi atau kualitas SDM.

Tujuan pembelajaran di sekolah yang merupakan proses interaksi antara pendidik, peserta didik dan sumber belajar harus berorientasi atau berbasis pada upaya untuk menjadikan peserta didik siap dan mampu menghadapi permasalahan hidup pada zaman atau abad yang dikenal dengan abad 21. Oleh karenanya, pendidikan formal ataupun nonformal sudah seharusnya berorientasi pada type pembelajaran abad 21 yang mengintegrasikan antara kemampuan literasi, kecakapan pengetahuan, keterampilan dan sikap, serta penguasaan teknologi.

Kemampuan literasi dianggap sebagai bagian terpenting dalam proses pembelajaran dan pengembangan pendidikan di semua jenjang atau level pendidikani. Hal tersebut tentu sangat beralasan, dimana peserta didik yang dapat melaksanakan kegiatan literasi dengan baik dan maksimal tentunya akan mendapatkan pengalaman belajar lebih dibanding dengan peserta didik yang memiliki kemampuan literasi yang rendah.

Literasi secara harfiah dan umumnya diartikan sebagai kemampuan membaca dan menulis. Dalam pembelajaran bahasa Inggris, guru seharusnya dapat menjadikan aktifitas membaca sebagai sarana dalam membekali para pelajar untuk memiliki kecakapan literasi yang memadai dengan melatih daya kritis mereka pada waktu membaca teks berbahasa Inggris dan salah satu strategi yang bisa digunakan untuk tujuan tersebut adalah dengan mendorong dan melatih para pelajar untuk mengajukan atau membuat pertanyaan terhadap apa yang mereka baca. Strategi yang dimaksud dalam konteks ini adalah merujuk pada model pembelajaran membaca berbasis question-generation yang merupakan hasil dari kegiatan penelitian tahun 2019 dan kegiatan pengabdian ini dilakukan sebagai bentuk desiminasi hasil penelitian.

Pembelajaran membaca berbasis question-generation terinspirasi dari fakta bahwa umumnya dalam pembelajaran bahasa Inggris pada keterampilan membaca, setelah para pelajar membaca sebuah teks, mereka diberikan sejumlah pertanyaan baik itu yang sudah ada dalam buku ajar atau pertanyaan yang diberikan oleh guru untuk mengukur sejauh mana pemahaman mereka terkait bahan atau teks yang mereka sudah baca. Dalam pembelajaran semacam ini, para pelajar dapat dikatakan sebagai objek atau bersifat "pasif", karena mereka yang ditanya. Mereka diarahkan untuk menjawab pertanyaan dan tidak untuk mengajukan atau membuat pertanyaan, sehingga akibatnya tidak banyak dari pelajar yang memiliki kemampuan bertanya atau mengajukan pertanyaan dengan kualitas yang baik, dan menurut White and Gunstone (1992), mengajukan pertanyaaan dalam pembelajaran adalah bukan peran yang biasa dijalankan oleh para pelajar. Dalam kegiatan membaca, secara umum dapat disimpulkan bahwa para guru tidak terbiasa atau bahkan mungkin tidak pernah mengajarkan atau melatih para peserta didik mereka untuk mengajukan atau membuat pertanyaan terkait teks yang mereka sudah baca.

Strategi membaca dengan membuat atau mengajukan pertanyaan mengenai bahan bacaan disebut dengan strategi Question-Generation yang dalam pengembannya didapatkan sebuah model pembelajaran Reading berbasis Question-Generation yakni sebuah model pembelajaran membaca yang mendorong atau melatih para pelajar untuk membuat pertanyaan terkait teks yang mereka baca. 
Model pembelajaran yang dimaksud tidak hanya menitik beratkan pada knowing what atau kecapakan berfikir tingkat rendah (LOTS) tetapi juga knowing how atau kecakapan berfikir tingkat tinggi (HOTS). Menurut Humphries dan Ness (2015), Question-Generation merupakan salah satu strategi membaca yang sangat menjanjikan, dimana para pembaca bertanya pada diri mereka sendiri tentang teks yang dibacanya yang dengannya dapat melatih keterampilan berfikir tingkat tinggi atau berfikir kritis. Lebih lanjut, White (1977) dalam Chin (2002) menyatakan bahwa kemampuan menyusun atau membuat pertanyaan adalah sebuah keterampilan yang perlu diajarkan kepada para siswa dan oleh karenanya guru seharusnya memberikan contoh pertanyaan dan mengajarkan bagaimana membuat pertanyaan.

Berdasarkan deskripisi diatas, kegiatan PPM ini bertujuan untuk berbagi informasi (sosialisasi) sekaligus untuk memperkaya pengetahuan para guru bahasa Inggris tentang strategi membaca dan bagaimana mengajarakannya yakni berupa model pembelajaran Reading berbasis Question-Generation.

\section{METODE}

PPM ini merupakan kegiatan sosialisasi yang meliputi penyajian materi (ceramah), diskusi, praktik penyusuan soal, dan evaluasi. Materi sosialisasi diadaptasi dari model pembelajaran Reading berbasis Question-Generation yang sudah diujicobakan pada kegiatan penelitian 2019 yang meliputi pengertian soal-soal HOTS dan level kognitif, karakteristik soal-soal HOTS, peran soal-soal HOTS dalam penilaian, bentuk/macam-macam soal (comprehension questions) dan prosedur pelaksanaan pembelajaran. Materi terkait soal-soal HOTS diambil dari Modul Penyusunan Soal Higher Order Thinking Skills (HOTS) yang diterbitkan oleh Direktorat Pembinaan SMA Direktorat Jenderal Pendidikan Dasar dan Menengah Departemen Pendidikan dan Kebudayaan (2017) dan dari Buku Penilaian Berorientasi HOTS yang diterbitkan oleh Direkorat Jendral Guru dan Tenaga Kependidikan Kementerian Pendidikan dan Kebudayaan (2018). Kegiatan PPM ini dilaksanakan di SMAN 1 Gunung Sari Lombok Barat pada hari Sabtu, 17 Oktober 2020 dan dihadiri oleh 20 orang bahasa Inggris SMA, SMK, MA di wilayah kecamatan Gunung Sari.

\section{HASIL DAN PEMBAHASAN}

Kegiatan PPM ini dilaksanakan di SMAN 1 Gunung Sari pada tanggal 17 Oktober 2020 dan dihadiri oleh bapak kepala SMAN 1 Gunung Sari dan 20 orang guru bahasa Inggris SMA, SMK dan MA di wilayah kecamatan Gunung Sari. Bapak kepala SMAN 1 Gunung Sari pada sambutannya menyambut baik kegiatan ini dan selalu mendukung semua kegiatan yang ditujukan untuk peningkatan SDM para guru.

Secara lebih rinci, ada beberapa hal yang dapat dideskripsikan sebagai hasil dari pelaksanaan kegiatan pengabdian kepada masyarakat ini, yakni:

1. Sesuai rencana dan undangan, kegiatan ini seyogyanya akan dihadiri oleh 30 orang guru, namun karena sebagian guru ada kegiatan lain di sekolah mereka dan juga alasan lainnya, maka yang berkesempatan hadir adalah sebanyak 20 guru.

2. Kegiatan ini dihadiri oleh bapak kepala SMAN 1 Gunung Sari dan pada pidato sambutannya, beliau menyambut baik kegiatan ini dan menyatakan akan selalu mendukung semua kegiatan yang ditujukan untuk peningkatan SDM, khususnya para guru.

3. Berdasarkan hasil angket dalam bentuk skala (grafik 1) yang diperoleh dari respon para guru terkait kegiatan pengabdian kepada masyarakat ini, dapat disampaikan bahwa: 


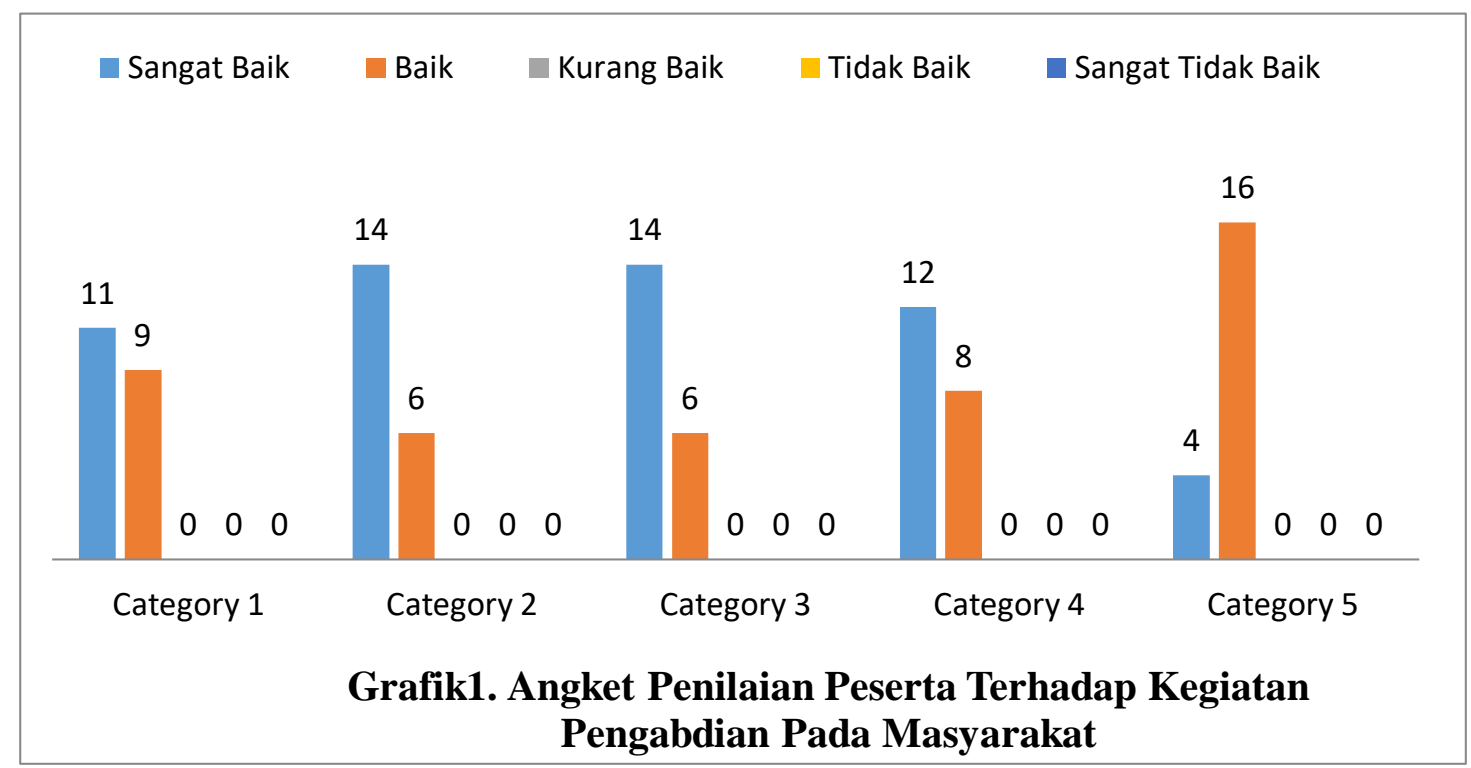

a. Pada kategori 1, terkait sarana-prasarana kegiatan sebagian besar (11 orang/55\%) menyatakan kalau sarana-perasarana dalam kegiatan pengabdian pada masyarakat ini adalah "sangat baik", sedangkan sisanya ( 9 orang/45\%) menyatakan "baik".

b. Kategori 2 adalah terkait layanan selama kegiatan. Pada kategori ini, sebagian besar peserta (14 orang/70\%) menyatakan "sangat baik", dan 6 orang (30\%) menyatakan "baik".

c. Pada kategori 3, tentang materi pelatihan, sebagian besar peserta (14 orang/70\%) menyatakan "sangat baik", dan 6 orang (30\%) menyatakan "baik".

d. Kategori 4 adalah tentang sistematika kegiatan pelatihan. Dalam hal ini, sebagian besar, 12 orang $(60 \%)$ menyatakan "sangat baik", dan 8 orang lainnya (40\%) menyatakan "baik"

e. Pada kategori 5, terkait konsumsi pelatihan, sebagian besar peserta (16 orang/80\%) menyatakan "baik", sedangkan yang lainnya, 4 orang (20\%) menyatakan "sangat baik".

4. Sedangkan pada angket terbuka (isian) yang menyangkut kesan dan harapan terhadap kegiatan PPM ini, respon para peserta dapat disimpulkan bahwa:

a. Secara umum para peserta menyatakan bahwa kegiatan seperti ini sangat bermanfaat karena dapat menambah pengetahuan dan wawasan bagi para guru yang secara tidak langsung dapat meningkatkan mutu pendidikan, oleh karenanya mereka berpendapat kalau kegiatan seperti ini sangat penting untuk terus dilakukan. Selain menjadi sarana untuk sharing pengetahuan dan pengalaman, sebagian peserta lainnya menyatakan bahwa kegiatan pengabdian ini sangat menarik dan inspiratif untuk menjadikan peserta didik lebih aktif khususnya dalam pembelajaran bahasa Inggris pada kegiatan reading.

b. Diantara harapan yang disampaikan oleh para peserta adalah terkait adanya tindak lanjut dari kegiatan serupa dengan durasi waktu yang lebih lama dan materi yang lebih banyak dan bervariasi. Materi yang disampaikan lewat power-point sebaiknya diprint-out dan diberkan kepada para peserta. Materi yang disampaikan sebaikanya lebih fokus pada teacher need dan problem solving, seperti penyusunan perangkat pembelajaran, supaya lebih aplikatif, dapat diterapkan langsung oleh para guru. Selain itu mereka juga berharap agar kegiatan serupa dapat melibatkan peserta atau guru bahasa Inggris dengan jumlah yang lebih banyak. 

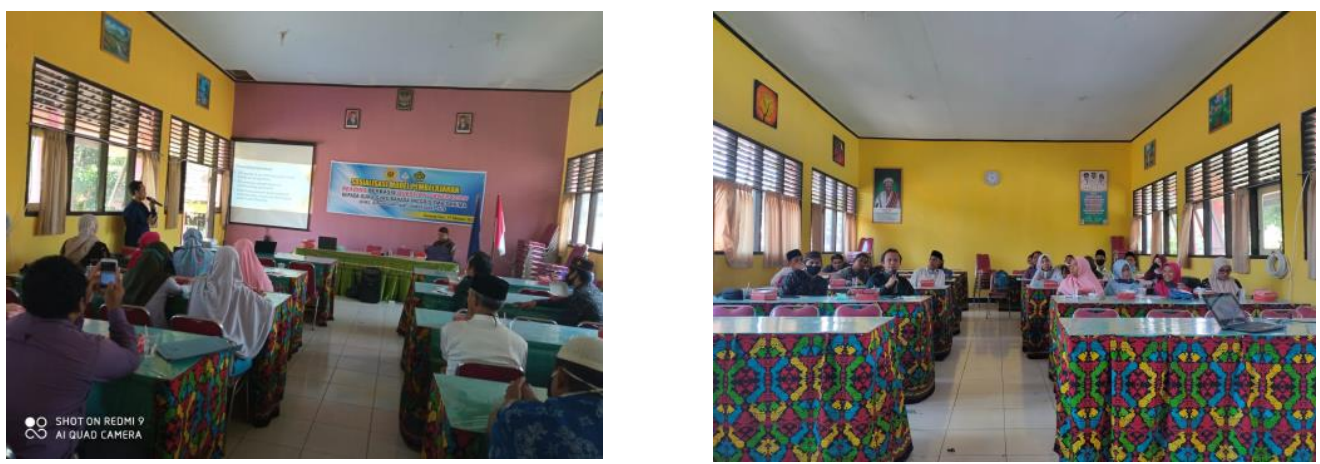

Gambar 2. Kegiatan Presentasi Materi (kanan) dan Tanya Jawab (kiri)

Dari hasil isian angket dan observasi selama kegiatan PPM ini berlangsung dapat dinyatakan jika para peserta menyambut baik kegiatan ini, dimana mereka terlihat antusias dalam mengikuti rangkaian kegiatan yang ada. Lebih lanjut, sesuai dengan pernyataan para peserta, kegiatan sosialisasi model pembelajaran membaca ini dianggap sangat bermanfaat karena dapat menambah pengetahuan dan wawasan mereka khususnya terkait strategi dan metode membaca dan juga bagaimana mengajarkan strategi membca tersebut kepada para peserta didik mereka yang dengan demikian kegiatan sosialisasi model pembelajaran membaca ini secara tidak langsung dapat meningkatkan mutu pendidikan.

Kegiatan PPM seperti ini dapat menjadi sarana komunikasi dan silaturahmi antara para guru itu sendiri dan juga antara para guru dan dosen, sehingga dengan demikian terwujud mutual benefit (saling menguntungkan) antara guru sebagai praktisi di lapangan dan para dosen sebagai konseptor dan praktisi di perguruan tinggi yang mendidik dan mencetak calon guru. Informasi dari para guru dan keadaan atau fakta di lapangan (sekolah) dapat menjadi pertimbangan dan rujukan dalam menyiapkan mahasiswa calon guru yang dapat memenuhi tuntutan dan/atau kebutuhan sekolah.

Selain itu, kegiatan PPM yang dilakukan oleh dosen dan yang melibatkan para guru tidak hanya untuk terwujudnya pelaksanaan tri dharma perguruan tinggi tetapi juga sebagai upaya untuk meningkatkan sumber daya manusia dan menjalin kerja sama antara perguruan tinggi dan masyarakat yang dalam hal ini adalah Sekolah Menengah Atas yang merupakan sumber mahasiswa bagi perguruan tinggi..

\section{KESIMPULAN DAN SARAN}

Dari penjelasan hasil dan pembahasan maka dapat disimpulkan bahwa kegaiatan sosialisasi telah terlaksana dengan baik dimana para guru yang terlibat menyambut baik kegiatan ini, mereka antusias mengikuti rangkaian kegiatan dan meraka berharap adanya tindak lanjut atau kegiatan serupa pada waktu yang lain dengan melibatkan peserta yang lebih banyak dan dengan materi atau topik yang lebih bersifat problem solving. Kegiatan PPM yang melibatkan para guru seperti ini seharusnya terus dilakukan oleh para dosen sebagai salah satu kegiatan dari tri dharma perguruan tinggi dan sebagai bentuk sumbangsih dalam upaya meningkatkan sumber daya manusia.

\section{Ucapan Terima Kasih}

Ketua dan tim pelaksana kegiatan PPM ini menghaturkan terimakasih banyak kepada Universitas Mataram yang dalam hal ini LPPM Universitas Mataram atas dukungan dana yang sudah diberikan demi teralaksana dan suksesnya kegiatan PPM ini. 


\section{DAFTAR PUSTAKA}

Chin, Christine. 2002. Student-Generated Questions: Encouraging Inquisitive Minds in Learning Science. Teaching and Learning, 23 (1), 59-67.

Depdikbud. 2017. Modul Penyusunan Soal Higher Order Thinking Skill (HOTS). Direktorat Pembinaan SMA Direktorat Jenderal Pendidikan Dasar dan Menengah.

Ekaningsih, A.S. 2013. Peran Pendidikan dan Pelatihan serta Kompetensi dalam Upaya Peningkatan Kualitas Sumber Daya Aparatur. Jurnal Borneo Administrator, Vol.9, No. 2

Humphries, J. \& Ness, M. 2015. Beyond Who, What, Where, When, Why, and How: Preparing Students to Generate Questions in the Age of Common Core Standards. Journal of Research in Childhood Education, 29: 551-564

Kemendikbud. 2018. Buku Penilaian Berorientasi Higher Order Thinking Skills. 2018. Program Peningkatan Kompetensi Pembelajaran Berbasis Zonasi. Direktorat Jendral Guru dan Tenaga Kependidikan

White, R.T., \& Gunstone, R.F. 1992. Probing Understanding. London: Falmer Press. 